Nuntius Antiquus, Belo Horizonte, v. 11, n. 1, p. 19-32, 2015

\title{
O teatro de Platão e a herança do "lógos" sofístico
}

\section{The theatre of Plato and the heritage of sophistic "logos"}

\author{
Anna Christina Silva \\ Universidade Estadual de Montes Claros (UNIMONTES), Montes Claros, Minas \\ Gerais, Brasil. \\ salomonsilva@yahoo.com.br
}

Resumo: Este artigo pretende colocar em evidência modelos interpretativos que valorizam a teatralidade do texto de Platão nos diálogos Crátilo e Protágoras. Para este fim, serão explicitados os vínculos que unem a forma do diálogo e o projeto filosófico defendido por Sócrates e seus interlocutores.

Palavras-chave: Platão; sofística; teatro; agón lógon .

Abstract: This article aims to highlight interpretative models that value the theatricality of the text in Plato's dialogues Cratylus and Protagoras. To this end, the ties that bind the form of dialogue and the philosophical project as defended by Socrates and his interlocutors will be explained.

Keywords: Plato; sophistic movement; theater; agón lógon .

Recebido em 29 de abril de 2015. Aprovado em 08 de julho de 2015. 


\title{
1 Introdução
}

\begin{abstract}
Por que Platão, expulsando de sua própria República os poemas homéricos por serem miméticos, agora no Crátilo os introduz como mestres inspirados da correção dos nomes? Será que na República era inapropriado o variado da imaginação diante dos costumes simples e corretos, enquanto aqui, no Crátilo, ele acolhe e abraça a sua inspiração? (PROCLO, Leituras do "Crátilo" de Platão, LXX-15-20)
\end{abstract}

Para os antigos leitores de Platão os diálogos pertencem a um estilo literário específico, os lógoi sokratikoí, onde estão enraizados e cristalizados conceitos filosóficos.

Dois importantes testemunhos vindos da antiguidade ilustram esta concepção híbrida, segundo a qual os diálogos platônicos sintetizam literatura e filosofia ao colocar em cena personagens e fatos que representam dramaticamente uma mensagem conceitual: o primeiro testemunho é o de Aristóteles, o segundo é o de Diógenes Laércio:

A arte que se utiliza apenas de palavras, sem ritmo ou metrificação, estas seja com variedades de metros combinados, seja usando uma só espécie de metro, até hoje não recebeu um nome. Não dispomos de nome que dar aos mimos de Sófron e Xenarco ao mesmo tempo que aos diálogos socráticos e às obras de quem realiza a imitação por meio de trímetros, dísticos elegíacos ou versos semelhantes. ${ }^{1}$ (ARISTÓTELES, Poética, I)

Dizem que o primeiro escritor de diálogos foi Zenão de Eleia, mas Aristóteles afirma no livro primeiro de sua obra Dos Poetas, que foi Alexâmenos de Estira ou Teos. Na minha opinião e de pleno direito, o verdadeiro inventor do diálogo é Platão, que pelo domínio do estilo pode reivindicar para si mesmo o primado tanto da beleza como da própria invenção. Um diálogo é um discurso composto de perguntas e respostas em torno de uma questão filosófica ou política, com uma caracterização conveniente dos personagens apresentados e com uma elocução acurada. A dialética é a arte da discussão com o objetivo de refutar ou aprovar uma

\footnotetext{
${ }^{1}$ Utilizei a edição brasileira, traduzida e organizada por Jaime Bruna (1997).
} 
tese por meio de perguntas e respostas dos interlocutores (DIÓGENES LAÉRCIO, Vidas, III, 48). ${ }^{2}$

Aristóteles destaca em sua Poética que a arte literária sem nome à qual pertencem os diálogos de Platão se aproxima dos "mimos", gênero dramático que representa de forma cômica e satírica episódios da vida cotidiana. $\mathrm{O}$ estagirita também concede destaque ao caráter mimético dos diálogos que utilizam a prosa em lugar do verso para imitar as ações humanas. O ponto de vista de Diógenes Laércio apresenta características que são comuns aos demais diálogos socráticos, como os de Xenofonte, por exemplo. Contudo, Diógenes Laércio observa que Platão se destacou dos demais escritores graças à representação da dialética desenvolvida numa forma literária "acurada" que coloca a pesquisa filosófica em ação.

Estes dois exemplos pertencem a uma rica tradição de interpretação da forma platônica do diálogo, tradição que podemos reconstruir, aproximando a crítica antiga e a recepção moderna das obras de Platão.

\section{Cenas de um conflito filosófico: o "agón lógon" no Crátilo e no Protágoras}

O helenista francês Louis Méridier dedicou ao diálogo platônico Crátilo uma tradução precedida de uma detalhada monografia, onde apresenta uma curiosa observação sobre a estrutura deste diálogo:

Em linhas gerais, o plano do Crátilo lembra aquele do Protágoras. Sócrates, neste último diálogo, começa por contestar a tese de Protágoras de que a virtude possa ser ensinada. Mas a discussão final conduz à inversão das posições defendidas no início, e é Sócrates que acaba provando para Protágoras, e contra si mesmo, que é possível ensinar a virtude. Há, portanto, entre as duas obras uma diferença essencial. No Protágoras, a segunda discussão parece refutar inteiramente a primeira; diferente do que ocorre no Crátilo, onde a segunda discussão é dedicada a corrigir, mas sem anular, as conclusões alcançadas na primeira discussão. (MÉRIDIER, 1950, p. 14)

Esta curiosa aproximação entre os dois diálogos platônicos

${ }^{2}$ A edição utilizada foi traduzida por Mário da Gama Cury (1988). 
sugerida por Louis Méridier é o meu ponto de partida para analisar as teses de Protágoras e Pródico, personagens que Platão caracteriza com muito zelo e que, na minha opinião, foram concebidos não para dar nascimento a doutrinas inteiramente elaboradas, mas para atuarem como catalisadores que suscitam a investigação autônoma, favorecendo a pesquisa dialética em comum (syzéte sis).

Encontramos no Crátilo e no Protágoras passagens em que Sócrates apresenta a intervenção dos sofistas como um guia para a pesquisa em comum:

Se, da minha parte, eu tivesse ouvido da boca de Pródico a lição de cinquenta dracmas que dá ao ouvinte um conhecimento completo da questão, nada te impediria de saber em um instante a verdade sobre a justeza dos nomes. Mas eu ouvi apenas a lição de um dracma; ignoro, portanto, qual é a verdade neste assunto. Por outro lado, estou disposto a pesquisar junto (syzêteîn) com você e com Crátilo. (PLATÃO, Crátilo, 384b4-c3)

Não penses, Protágoras, que ao dialogar (dialégesthai) contigo move-me outra intenção que não seja a de esclarecer certos problemas que me parecem aporéticos. Sou de opinião que Homero tinha toda razão ao dizer: Quando são dois, se um não vê, o outro logo percebe o caminho. Deste modo, juntos nos preparamos melhor para qualquer obra, discurso e pensamento (érgon kai lógon kái dianóéma). Mas, quando àquele que está só ocorre qualquer pensamento, sai à procura de alguém com quem possa investigar (zêtêi) até conseguir demonstrar (epideíxetai). Por isso, tenho mais prazer (hédéos) em dialogar contigo do que com qualquer outra pessoa, convencido como estou, de que és o homem mais competente para analisar os problemas em geral e, especialmente, o problema da virtude. (PLATÃO, Protágoras, 348c6-e1)

Em ambos os diálogos, Sócrates mostra que, para ele, a atividade filosófica, a aspiração ao saber e o desejo de instruir os interlocutores 
dependem do encontro confrontador com as teses de Pródico e Protágoras. ${ }^{3}$ As referências aos sofistas podem ser reduzidas a um formato mínimo, como a breve aparição de Pródico e Protágoras que são citados no início do diálogo Crátilo, ou podem ocupar uma parte significativa e até mesmo a totalidade do diálogo como ocorre no Protágoras. Werner Jaeger, ao interpretar esta trama de relações e aparições que unem Sócrates e os sofistas, valoriza as influências exercidas pela "teatrocracia" ateniense e pela proliferação dos lógoi sokratikoí, sugerindo que a análise da forma literária escolhida por Platão para representar "a luta de dois mundos opostos pelo primado da educação" oferece um terreno fecundo de pesquisa (JAEGER, 1995, p. 585-591).

O estudo das estratégias de comunicação dos diálogos como via de acesso privilegiado para compreendê-los foi amplamente explorado pela helenista americana Raquel Barney, que se dedicou ao estudo do Crátilo. Para Barney, Platão estabelece no Crátilo um surpreendente paralelo entre a competição intelectual e a competição atlética. Este paralelo leva a helenista a caracterizar o diálogo como um diálogo agonístico, onde a disputa intelectual de Sócrates com Protágoras, Pródico e Homero oferece respostas satisfatórias para o problema da tão discutida seção etimológica. Nos capítulos intitulados "The agonistic display" e "The etymologies as 'agon", Barney sugere que a disputa agonística coloca em funcionamento as estratégias epistemológicas tão habilmente construídas por Platão ao longo do diálogo. Ela demonstra que o modelo epistemológico que resulta do agón lógon é que dá uma fisionomia característica ao método dialético, visto que é na medida em que toma parte desta luta de argumentos que a filosofia de Platão almeja triunfar sobre a hegemonia pedagógica exercida pela retórica e pela poesia (BARNEY, 2001, p. 57-60).

Tomemos como exemplo as referências a Homero analisadas pela autora. Nas passagens 407d7-410e 3 e 414b2-3, Sócrates, ao discutir com Hermógenes a grande dificuldade que envolve a questão da possibilidade de determinação das regras racionais que legitimam o uso dos nomes, faz referência à corrida de carruagem retratada na Ilíada $(\mathrm{V}, 221-222 \mathrm{e}$ XXIII, 315-325), onde os heróis gregos buscavam a vitória orientados

\footnotetext{
${ }^{3}$ Sobre as características dos lógoi sokratikoi e sobre a intertextualidade utilizada por Platão para criticar os tradicionais gêneros de discursos e para definir a nova prática discursiva que ele chama de filosofia, cf. NIGHTINGALE, 1996, p. 1-12.
} 
pela $m \underline{e}$ tis - a astuciosa sabedoria. O momento estratégico do diálogo sugere um impasse que coloca em jogo o sucesso da pesquisa, quando é verificada a precariedade do conhecimento das coisas através dos nomes. Sócrates, diante deste impasse, anuncia-se como um novo herói homérico que vai assumir seu posto numa disputada e árdua corrida. Para garantir a vitória, ele também recorre ao modelo epistemológico utilizado pelos heróis homéricos: a mêtis. Segundo Barney, a performance agonística de Sócrates no Crátilo representa a herança de uma prática cultural cujo realçamento não é menos significativo para a compreensão do seu discurso etimológico. Para a autora, é a interação do ágon platônico que assimila a mêtis de Sócrates ao poder das Musas que ajuda o leitor atento a ouvir melhor as harmonias e dissonâncias insolúveis das etimologias socráticas. O que é essencial na seção etimológica é o seu enraizamento nos problemas metodológicos. Barney está convencida de que a presença agonística das etimologias indica que Platão buscou superar a polyphonía dos métodos empregados pelos sofistas e pelos poetas, para estabelecer a excelência do método dialético. A batalha das práticas intelectuais gera uma verdadeira "anarquia metodológica" que transcende o Crátilo e, na opinião da helenista, esta batalha pode ser identificada nos diálogos Menéxeno, Fedro e Protágoras. Os ágones do Menéxeno e do Fedro envolvem disputas retóricas, o do Protágoras diz respeito a uma disputa literária e interpretativa (BARNEY, 2001, p. 6465). Basta-nos, porém, considerar o problema do agón no Crátilo e no Protágoras para nos convencermos de sua importância para os debates críticos e para a interpretação dos diálogos. ${ }^{4}$

Minha exposição se esforçará por enquadrar os contornos modeladores deste problema, acentuando as relações entre Platão e os sofistas citados nos referidos diálogos. É assim que pretendo intervir na interpretação de Barney, transferindo o foco do agón, no Crátilo, dos poetas para os sofistas Protágoras e Pródico e, no Protágoras, dos sofistas para Aristófanes.

Começo pelo Crátilo, pela cena em que Sócrates aproxima a tese convencionalista de Hermógenes da célebre frase do "homem medida" presente nos escritos de Protágoras (385e7-386a6). Não é por

\footnotetext{
${ }^{4}$ Sobre o diálogo Menéxeno, acredito que o agón do diálogo visa a Antifonte através do seu discípulo Tucídides. Escrevi um artigo sobre o tema intitulado: Antifonte, Aspásia e Sócrates no “Menéxeno” de Platão (Poiêsis, Montes Claros, vol. 7, n. 1, p. 11-23, 2011).
} 
acaso que muitos helenistas vincularam o relativismo de Protágoras, supostamente derivado da célebre frase, ao convencionalismo de Hermógenes. Torna-se assim muito natural, segundo a interpretação de David Sedley (2003, p. 54-55), que ao recusar a tese relativista de Protágoras, o convencionalismo linguístico defendido por Hermógenes seja prontamente refutado por Sócrates. Não é só por acaso, observa Louis Méridier (1950, p. 45), que, no Crátilo, Protágoras seja mostrado como o representante "de uma sofística relacionada ao sistema de Heráclito". Fundamentalmente, afirma Catherine Dalimier (1998, p. 29), no Crátilo a tese de Protágoras coincide com a tese individualista do conhecimento desenvolvida no Teeteto.

Por outro lado, devemos voltar o olhar para um segundo ponto de vista. São dignas de nota a tensão e a elasticidade da leitura bem afiada e treinada apresentada por Kerferd. Para ele, o ponto de partida do Crátilo é "uma questão saída dos debates sofísticos" (KERFERD, 1999, p. 128). Kerferd mostra com astúcia que o enraizamento sofístico do problema da correção dos nomes invade o solo seguro por onde Hermógenes acredita caminhar depois de ter recusado a tese de Protágoras. Para o helenista, Hermógenes, ao recusar a Verdade de Protágoras, preferindo, como sugeriu Sócrates, recorrer à sabedoria de Homero, volta a pisar em solo minado. Desde que Homero mostrou em seus poemas, como afirma Sócrates, que os deuses nomeiam as coisas empregando nomes corretos que são diferentes daqueles empregados pelos mortais, ficou consagrada a teoria da correção natural nos nomes. Segundo Kerferd, esta teoria naturalista de origem homérica encontrou sua expressão lapidar diante da filosofia de Protágoras. Como legitimo herdeiro da sabedoria poética, Protágoras, no diálogo platônico que leva seu nome, aceita a teoria da correção natural dos nomes ao narrar a origem da linguagem. No mito de Prometeu, Protágoras explica que a humanidade recebeu como dom divino a voz e os nomes: phoneîn kaì onómata (PLATÃO, Protágoras, 322a). Assim, conclui Kerferd (1999, p. 129), para Protágoras a possibilidade de nomear as coisas com "arte" tem origem num dom natural.

Este esforço empreendido por Kerferd, de compreender o papel desempenhado por Protágoras no Crátilo à luz do diálogo Protágoras, coincide com o trabalho hermenêutico desenvolvido por Dupréel no livro Les sophistes. Segundo Dupréel, no Crátilo, Hermógenes e Crátilo são representantes de dois pontos de vista distintos que correspondem à posição adotada por Protágoras. Um desses aspectos, observa o autor, é 
o caráter convencional da linguagem, "seu valor social". O outro aspecto diz respeito à "coincidência rigorosa" entre o nome e a coisa nomeada (DUPRÉEL, 1948, p. 37). Grata surpresa esta que nos propicia Dupréel, ao nos fazer encontrar Protágoras defendendo antilogicamente teses opostas. Comparando a tese do "homem medida" citada por Platão com o testemunho de Sexto Empírico, Dupréel (1948, p. 38-51) pretende mostrar que foi Protágoras quem inaugurou a controvérsia sobre a propriedade dos nomes que "se tornou famosa" ao fornecer elementos para os "paradoxos divertidos" como as "etimologias fantasiosas". O tratado da correção dos nomes escrito por Protágoras, sugere Dupréel, não tinha como objetivo corrigir a língua, mas visava a ensinar o bom uso, utilizando as melhores referências oferecidas pelos poetas. Este tratado pertencia à grande obra do sofista intitulada Da Verdade, e foi nela que Sexto Empírico encontrou uma inovadora teoria da matéria (hýle ) associada ao funcionamento da linguagem (lógos). ${ }^{5}$ Sexto Empírico procura dar um novo significado à tese do "homem medida" ao afastarse da interpretação de Platão, aproximando Protágoras de Pirro. É deste modo que ele pretende mostrar que, para o sofista de Abdera, os nomes estão, desde sempre, presentes na matéria indeterminada e amorfa, visto que são os nomes que concedem determinação à matéria, pois nomear é recortar as coisas que estão plasmadas na matéria amorfa, dando a elas sua forma final. Mas, como adverte Dupréel, embora haja na doutrina de Protágoras transmitida por Sexto uma "solidariedade completa" entre o nome e aquilo que é nomeado, todas as palavras que estão contidas na matéria estão à disposição dos seres humanos que as adotam seguindo as suas conveniências, pois, de todas as coisas (prágmata) o homem é o critério (kritérion) que institui a "convenção determinante", recortando o "fixo no movente" (DUPRÉEL, 1948, p. 48).

Segundo Dupréel, além da formulação da doutrina protagoreana, também encontramos no Crátilo uma nítida alusão às teses que foram defendidas por Hípias no diálogo Protágoras. Dupréel (1948, p. 36) está convencido de que "o historiador não pode encontrar no Crátilo esclarecimentos sobre o pensamento de Protágoras, se não analisar o diálogo juntamente com a doutrina de Hípias". E aplicando a linguística a uma teoria sobre o conhecimento da natureza dos seres que Hípias se opõe a Protágoras. Para o helenista francês, na passagem 386d-e do

\footnotetext{
${ }^{5}$ Utilizo a edição dos fragmentos de Protágoras organizada por Untersteiner (1967).
} 
Crátilo, Hermógenes, ao admitir que "as coisas possuem em si mesmas um ser permanente, que não é nem relativo à nós e nem depende de nós", descreve de modo adequado e preciso a teoria de Hípias. Esta tese da supremacia da natureza sobre a precariedade das convenções foi defendida por Hípias na passagem 337c-d do diálogo Protágoras. Deste modo, conclui o helenista, Platão, no Crátilo, retoma as controvérsias do diálogo Protágoras ao acentuar as divergências existentes entre as teses de Protágoras e Hípias (DUPRÉEL, 1948, p. 267).

A construção desse debate sofístico entre Protágoras e Hípias transposto do Crátilo para o Protágoras suporta ainda a inclusão do sofista Pródico. Sobre Pródico, encontramos nas passagens 338e-347a do diálogo Protágoras o sofista de Céos interpretando os versos de Simônides sobre a virtude. Esta intervenção do sofista nos leva, segundo Dupréel, ao problema da sinonímia, da distinção do significado correto de termos semelhantes. Contudo, a nova forma de conceber as doutrinas de Pródico proposta pelo helenista em nada se assemelha ao tom jocoso adotado por Platão nos dois diálogos em questão. Ele acredita que Pródico foi um moralista que elaborou uma sofisticada teoria sobre a educação voltada para a aquisição da virtude (areté). Pródico dedicou-se a distinguir as nuances dos sentimentos, elogiando a ponderação e distinguindo os estados da alma diante de situações impulsivas como o desejo e a cólera. Para Dupréel, o alto apreço pelos valores éticos que Pródico propagava em suas lições nada tem a ver com o comentário debochado sobre a lição de cinquenta dracmas que Sócrates faz no início do Crátilo (384b) (DUPRÉEL, 1948, p. 180-181).

Pensemos agora nesta equiparação das doutrinas dos sofistas e na reintegração que delas fizemos ao aproximar o Crátilo e o Protágoras, tendo em vista seus aspectos dramáticos. Falamos da semelhança estrutural que harmonicamente aproxima os dois diálogos, sugerida por Louis Méridier. Voltamos agora a nossa atenção para encontrar nessa semelhança a simbiose de uma tradição literária-poético-filosófica que orienta o valor do conteúdo filosófico e a função pedagógica dos diálogos. Procuremos imaginar singelamente a discussão entre Sócrates e os sofistas a respeito do problema da correção dos nomes sob a forma corrente dos diálogos socráticos, ou seja, como sucessão ininterrupta de tentativas de definição e logo compreenderemos por que é que Platão preferiu compor o Crátilo e o Protágoras intercalando os discursos dos personagens. É principalmente na forma do diálogo que o agón dramático 
de Sócrates alcança o triunfo e, indubitavelmente, o ponto culminante dos dois diálogos é o primado da filosofia sobre a sofística e sobre a poesia. No entanto, acredito que, para alcançar esta dignidade, a filosofia teve de criar obras poéticas, ou seja, teve de converter-se também em poesia. Logo, com a escolha dos personagens e do cenário, Platão faz Sócrates reviver no Crátilo e no Protágoras as grandes disputas intelectuais do século V. O Crátilo em simetria com o Protágoras congrega os principais sofistas em torno da figura de Cálias, o homem mais rico de Atenas, que muito dinheiro investiu nas lições dos sofistas e que nada dividiu com seu miserável irmão Hermógenes. Assim como Hermógenes, Crátilo desempenha um papel enigmático, pois ambos são caracterizados de maneira muito sumária. É Hermógenes que abruptamente entra em cena convidando Sócrates para discutir a tese de Crátilo. Crátilo ocupa a cena final do diálogo, onde aparece como defensor heraclítico do naturalismo linguístico. Neste entreato é apresentado o longo discurso etimológico de Sócrates, cujo molde em tudo se assemelha com a makrología praticada pelos sofistas. A dramaticidade do diálogo culmina com a inversão das teses de Hermógenes e Crátilo operada por Sócrates. No fim do primeiro ato ou da primeira "dialogação" é Crátilo quem vence, pois Sócrates refuta Hermógenes. Já no fim do segundo ato ou da segunda "dialogação" quem vence a disputa é Hermógenes, pois Sócrates derrota o argumento de Crátilo. O agón termina em empate. Empate que sugere a vitória da teoria das Formas? Aqui só podemos adiantar uma resposta sumária: há controvérsias!

Voltando o nosso enfoque ao lugar de destaque concedido por Platão ao grande discurso etimológico de Sócrates, não devemos deixar de lembrar que a sua extensão desproporcional levou o helenista francês Louis Méridier (1950, p. 33) a afirmar que a sua forma literária compromete a totalidade do diálogo do ponto de vista artístico. Ora, o mais elementar a que nos podemos ater não é a extensão desproporcional da seção etimológica, mas sim a influência direta de muitas práticas metodológicas que foram plasmadas neste discurso agonístico do filósofo. A semelhança entre o agón platônico e o agón literário da tragédia e da comédia reside, na minha opinião, na explicitação do conflito que representa para os personagens um obstáculo quase insuperável e que exige uma tomada de decisão iminente. Acredito que a formulação do tema justifica esta disposição cênica do diálogo, estabelecendo a excelência da forma dialógica como o único caminho possível para a investigação filosófica, excelência baseada numa disputa que foi nutrida pela sofística. 
Seja-nos permitido encerrar esta discussão sobre o tema do agón lógon fazendo uma breve digressão sobre o tema no diálogo Protágoras. Convém relembrar o que foi dito anteriormente: há entre o Crátilo e o Protágoras uma simetria estrutural e uma simetria de conteúdo. As teses dos sofistas dialogam nos dois textos como nos mostraram Kerferd e Dupréel. E a inversão das teses dos interlocutores operada por Sócrates também comparece em ambos os diálogos. É nesta encruzilhada que se unem os caminhos de Platão e Aristófanes. Para unir os caminhos do filósofo e do comediógrafo, utilizo como guia os estudos do helenista italiano Andrea Capra. No livro Agón lógon: il "Protagora" di Platone tra eristica e commedia, Andrea Capra propõe analisar a complexa trama de relações que unem diálogo e comédia. Para ele, a essência do Protágoras se encontra no agonismo dos personagens. $\mathrm{O}$ autor nos mostra que a incorporação do agón cômico no diálogo acontece através de uma fusão que une a estrutura da comédia As nuvens de Aristófanes e a ambientação da comédia perdida de Êupolis (2001, p. 86-88), Os aduladores. Segundo Capra, na peça de Êupolis, os sofistas reunidos na casa de Cálias desenvolviam argumentos falaciosos e exploravam os jovens endinheirados, assim como acontece no pensatório de Sócrates descrito n'As nuvens de Aristófanes. A analogia com o Protágoras é explícita e várias cenas típicas da comédia são identificadas pelo autor.

Entre as cenas cômicas convém indicar a mudança de cenário, o episódio da porta fechada e a estrutura agonística do confronto dialético. No Protágoras, a mudança de cenário é feita da casa de Sócrates, onde o diálogo começa, para a casa de Cálias, onde o diálogo se desenvolve. O contraste entre os dois cenários é exageradamente risível: a casa paupérrima de Sócrates é comparada com a rica mansão de Cálias. A mesma mudança de cena ocorre n'As nuvens, porém os personagens estão invertidos na ordem das cenas. Aristófanes inicia sua peça na casa do rico "submergente" Estrepsíades e transfere a performance para o pensatório pulguento do sofista Sócrates. A segunda cena típica diz respeito ao tema cômico da porta fechada. Ao mudar de ambiente, o personagem é transposto para um novo universo de valores desconhecidos, por isso a porta fechada e a presença do porteiro são fundamentais para caracterizar esta transição. N'As nuvens o porteiro do pensatório é Querofonte, o discípulo morfético de Sócrates, e no Protágoras o porteiro é o lacaio entediado de Cálias. Por fim, a última cena cômica, que é a mais importante para o presente estudo, representa o conflito verbal entre 
dois personagens. A força do efeito dramático deste agón opõe Sócrates e Protágoras, que lutam usando o grande discurso (makrología) como arma. Segundo Andrea Capra (2001,p. 71-78), é o mimetismo das técnicas do sofista e das técnicas dos poetas que caracteriza o agón platônico.

Conclusão muito conveniente e que serve perfeitamente para reforçar os pontos de contato que tentei estabelecer entre o Crátilo e o Protágoras. Acredito que em ambos os diálogos é a polifonia da escritura agonística de Platão que, por ser capaz de integrar diversos gêneros de discurso, produz o mais mimético dos gêneros - o diálogo.

Não há dúvida de que a interpretação agonística dos referidos diálogos põe em relevo questões importantes relacionadas com a atitude artística adotada por Platão. Acredito que esta chave de leitura não reduz o fenômeno multiforme da filosofia platônica à superficial oposição forma literária versus conteúdo filosófico; tampouco estabelece que Platão foi um poeta e não um filósofo. Hegel já se vê obrigado nas suas Lições sobre a história da filosofia a reconhecer a impossibilidade de separar o que é inseparável, ao apresentar historicamente a filosofia platônica como uma totalidade conceitual orgânica unida ao material mítico, dramático, próprio da forma dialogada da sua escritura (HEGEL, 1965, p. 146). Contudo, Hegel tropeça e, com dificuldade, tenta conciliar a filosofia de Platão com seu próprio sistema, mostrando que a forma dialógica escolhida por Platão é sim uma "bela forma", mas não é a "melhor". É por isso que Hegel, após ter admitido que forma e conteúdo constituem nos diálogos uma unidade inseparável, precisa resolver uma operação contraditória:

As obras platônicas reconhecidamente são diálogos, e primeiro é preciso falar da forma em que Platão expôs suas ideias, caracterizá-la; mas por outro lado é preciso separá-la do que neles é propriamente filosofia. (HEGEL, 1965, p. 149-150)

A meu ver, a atitude contraditória de Hegel se impôs, vitoriosa, diante das tentativas de interpretação da expressão artística da filosofia platônica. Se repararmos naqueles críticos da escola anglo-americana que reconhecem apenas o valor isolado dos argumentos, priorizando uma análise lógica e conceitual dos diálogos, teremos, necessariamente, de concluir que a contradição hegeliana não foi ainda superada. ${ }^{6}$ Contudo,

\footnotetext{
${ }^{6}$ Sobre a leitura analítica dos diálogos de Platão, Christopher Gill apresenta em seu artigo Le Dialogue Platonicien uma detalhada reconstrução dos principais modelos de leitura adotados pela crítica recente. (GILL, 2008, p. 53-73)
} 
o reconhecimento desta hegemonia não significa a aceitação de todas as conclusões que se tiraram a respeito das obras de Platão através da utilização do critério analítico. Apesar disso, é possível não sentir o desamparo no meio desta escuridão; ao contrário, devemos nos sentir guiados pela mêtis de Sócrates, símbolo da ruptura, representação do étimo cratiliano para a palavra Musa - "desejar conhecer” (406a).

\section{Referências}

Fontes primárias

ARISTÓTELES. Arte poética. Trad. Jaime Bruna. São Paulo: Cultrix, 1997.

ARISTÓFANES. As nuvens. Trad. Gilda de Melo Souza. São Paulo: Editora Abril, 1983.

DIÓGENES LAÉRCIO. Vidas e doutrinas dos filósofos ilustres. Trad. Mario da Gama Cury. Brasília: UNB, 1988.

HEGEL, G. W. F. Lecciones sobre la historia de la filosofia. Trad. Wenceslao Roces. México: Fondo de Cultura Económica, 1965.

PLATÓN. Protágoras. Trad. Ute Schimidt Osmanczik. Ciudad del México: UNAM, 1994.

PLATON. Cratyle. Trad. Louis Méridier. Paris: Les Belles Lettres, 1950. PROCLO. Lecturas del "Crátilo” de Pláton. Trad. Jesús Maria Alvarez y Jose Garcia. Madrid: Ediciones Akal, 1999.

\section{Fontes secundárias}

BARNEY, R. Names and nature in Plato's Cratylus. New York: Routledge, 2001.

CAPRA, A. Agón lógon: il "Protagora" di Platone tra eristica e commedia. Milano: L.E.D., 2001.

DUCHEMIN, J. L'agon dans la tragédie grecque. Paris: Les Belles Letres, 1945.

DUPRÉEL, E. Les sophistes. Neuchâtel: Éditions du Griffon, 1948.

DALIMIER, C. Introdução, trad. e notas. In: PLATON. Cratyle. Paris: Flammarion, 1998, p.11-64. 
GILL, C. Le dialogue platonicien. In: BRISSON, L.; FRONTEROTTA, F. (org.). Lire Platon. Paris: PUF, 2008, p. 53-75.

JAEGER, W. Paideia. Trad. Arthur M. Parreira. São Paulo: Martins Fontes, 1994.

KERFERD, G. B. The sophistic movement. London: Cambridge University Press, 1981.

MÉRIDIER, L. Introdução, trad. e notas. In: PLATON. Cratyle. Paris: Les Belles Lettres, 1950, p. 18-59.

NIGHTINGALE, A. W. Genres in dialogue: Plato and the construct of philosophy. Cambridge: Cambridge University Press, 1996.

SILVA, A. C. Antifonte, Aspásia e Sócrates no "Menéxeno" de Platão. Poiêsis, Montes Claros, vol. 7, n. 1, p. 11-23, 2011.

SEDLEY, D. Plato's Cratylus. New York: Cambridge University Press, 2003.

UNTERSTEINER, M. I sofisti: testemonianze e frammenti. Firenze: La Nuova Italia, 1967. 